\title{
Submerged Fermentation of Animal Fat By-Products by Oleaginous Filamentous Fungi for the Production of Unsaturated Single Cell Oil
}

\author{
Sushil S. Gaykawad ${ }^{1}$, Sreerekha S. Ramanand ${ }^{1}$, Johanna Blomqvist ${ }^{2}$, Boris Zimmermann ${ }^{2}\left(\mathbb{D}\right.$, Volha Shapaval ${ }^{2}{ }^{\mathbb{D}}$, \\ Achim Kohler ${ }^{2}$, Marije Oostindjer ${ }^{3}$ and Catherine Boccadoro ${ }^{1, *}$ \\ 1 Norwegian Research Centre AS (NORCE), Prof. Olav Hanssensvei 15, 4021 Stavanger, Norway; \\ susg@norceresearch.no (S.S.G.); srra@norceresearch.no (S.S.R.) \\ 2 Faculty of Science and Technology, Norwegian University of Life Sciences (NMBU), P.O. Box 5003, \\ 1432 Ås, Norway; Johanna.blomq5625vist@nmbu.no (J.B.); boris.zimmermann@nmbu.no (B.Z.); \\ volha.shapaval@nmbu.no (V.S.); Achim.kohler@nmbu.no (A.K.) \\ 3 Norilia AS, Lørenveien 37, 0585 Oslo, Norway; marije.oostindjer@norilia.no \\ * Correspondence: cabo@norceresearch.no
}

Citation: Gaykawad, S.S.; Ramanand, S.S.; Blomqvist, J.; Zimmermann, B.; Shapaval, V.; Kohler, A.; Oostindjer, M.; Boccadoro, C. Submerged Fermentation of Animal Fat By-Products by Oleaginous Filamentous Fungi for the Production of Unsaturated Single Cell Oil. Fermentation 2021, 7, 300

https://doi.org/10.3390/

fermentation7040300

Academic Editor: Diomi Mamma

Received: 31 October 2021

Accepted: 6 December 2021

Published: 9 December 2021

Publisher's Note: MDPI stays neutral with regard to jurisdictional claims in published maps and institutional affiliations.

Copyright: (c) 2021 by the authors. Licensee MDPI, Basel, Switzerland. This article is an open access article distributed under the terms and conditions of the Creative Commons Attribution (CC BY) license (https:// creativecommons.org/licenses/by/ $4.0 /)$.

\begin{abstract}
Animal waste fats were explored as a fermentation substrate for the production of high-value unsaturated single cell oil (SCO) using oleaginous fungi, Mucor circinelloides and Mortierella alpina. Both strains showed good growth and lipid accumulation when using animal fat as a single carbon source. The biomass concentration of $16.7 \pm 2.2 \mathrm{~g}_{\mathrm{DCW}} / \mathrm{L}$ and lipid content of $54.1 \%{ }_{\mathrm{wt}}$ (of dry cell weight) were obtained for Mucor circinelloides in shake flask experiments, surpassing the biomass yield achieved in batch and fed-batch fermentation. In contrast, Mortierella alpina gave the highest biomass concentration $\left(8.3 \pm 0.3 \mathrm{~g}_{\mathrm{DCW}} / \mathrm{L}\right)$ and lipid content $\left(55.8 \%{ }_{\mathrm{wt}}\right)$ in fed-batch fermentation. Fat grown Mortierella alpina was able to produce arachidonic acid (ARA), and the highest ARA content of $23.8 \%$ wt (of total lipid weight) was in fed-batch fermentation. Gamma-linolenic acid (GLA) was produced by both fungal strains. At the end of fed-batch fermentation, the GLA yields obtained for Mucor circinelloides and Mortierella alpina were $4.51 \%_{\mathrm{wt}}$ and $2.77 \%_{\mathrm{wt}}$ (of total lipid weight), respectively. This study demonstrates the production of unsaturated SCO-rich fungal biomass from animal fat by fermentation.
\end{abstract}

Keywords: animal fat; PUFA; oleaginous fungi; fermentation; lipids

\section{Introduction}

The global production and consumption of meat is projected to rise progressively over the next decade, largely driven by population and income growth [1]. This demand for meat will result in the increased production of slaughterhouse by-products from the meat processing industry. The animal fat is produced by rendering fat by-products in slaughterhouses. Edible and non-edible animal fats have been widely used in food, agriculture, and industrial applications [2,3]. Based on the animal by-products (ABP) regulation (1069/2009, 142/2011), the ABPs can be divided into three categories. Category 1 and 2 ABPs are not suitable for human and animal consumption, while category 3 by-products are of lowest risk and are fit for human consumption. However, today they are not used directly for human food, but as animal feed and for commercial purposes [3-5].

The nutritional and economical value of the fat is determined by its fatty acid composition which depends on the animal species. In general, animal fat is rich in saturated fatty acids (SAFs) and contains low amounts of polyunsaturated fatty acids (PUFAs). The most common fatty acids present in animal fat are palmitic (C16:0), stearic (C18:0), oleic (C18:1), and linoleic (C18:2) [6,7]. The polyunsaturated fatty acids (PUFAs), like linoleic acid (18:2, n-6), alpha-linolenic (ALA C18:3, n-3), arachidonic (ARA C20:4,n-6), eicosapentaenoic (EPA C20:5), and docosahexaenoic acid (DHA C22:6, n-3), are present in low amounts. Since 
there is a great interest in those fatty acids due to their medical and dietary application [8], upgrade of category 3 animal fat composition poses a great valorization interest.

Animal fats are widely used in animal feed, oleochemicals and soaps, energy generation, and biodiesel production [9]. Different processes have been proposed in literature for converting animal fat into high value products [4]. One of the proposed strategies is based on converting hydrophobic substrates (such as vegetable oils, volatile fatty acids, and animal fats) into valuable essential unsaturated single cell oils via fermentation by oleaginous microorganisms [3,10-18]. Oleaginous microorganisms have the ability to accumulate high amount of lipids (from $20 \%$ up to $80 \%$ of their dry cellular weight) in the form of triglycerides (TGAs) and free fatty acids. These lipids are accumulated as storage compounds of biomass and are generally referred to as single cell oil (SCO).

Among the oleaginous microorganisms, oleaginous filamentous fungi belonging to the genera Mucor and Mortierella are considered as potential candidates for SCO production due to their ability to utilize a wide range of low-cost substrates and accumulate high quantities of lipids (up to $70 \%$ of their weight in optimized growth media), including high content of valuable unsaturated fatty acids [19-26]. Strains Mucor circinelloides and Mortierella alpina have been used for commercial production of SCO, either for the production of oil rich in gamma-linolenic acid (GLA; 18:3, n-6) by Mucor circinelloides, or arachidonic acid by Mortierella alpina [27]. Nevertheless, due to the high production costs, the large-scale industrialization of microbial SCO has not been achieved. To make process economically viable, the integration of production of SCO with some other high-value compounds, as well as production based on low-cost substrates is being suggested [28]. Although these fungal strains can be cultivated on a wide range of feedstock $[9,29]$, the studies based on hydrophobic substrates such as animal fat are scarce [30,31].

In this study, we have considered submerged fermentation based on the oleaginous strains of Mucor circinelloides and Mortierella alpina for upgrading the category 3 animal fat by-products. The selected oleaginous microorganisms were cultivated on animal fat substrate to evaluate if it is suitable for the production of high-value unsaturated SCO. Moreover, the growth and lipid formation were studied, including the fatty acid composition of fungal SCO. This study established a proof of concept for the bioconversion of animal fat into valuable unsaturated SCO through the fermentation by oleaginous filamentous fungi. To our knowledge, this is the first report describing up-scaled submerged fermentation of animal fat by-products.

\section{Materials and Methods}

\subsection{Microorganisms}

The oleaginous filamentous fungi Mucor circinelloides VI10 (MC) and Mortierella alpina ATCC 32222 (MA) were provided by the Norwegian University of Life Sciences (Ås, Norway).

\subsection{Media Composition and Preparation of Inoculums}

For spore inoculum preparation, the fungal strains were cultivated on potato dextrose agar (PDA) at $25^{\circ} \mathrm{C}$ for 7 days, after which fungal spores were harvested in $10 \mathrm{~mL}$ sterile $0.9 \%(w / v)$ saline solution and used for inoculating shake flasks and mycelium inoculum preparation for bioreactor experiments.

Two broth media were used: the fat medium (FATM), containing animal fat byproducts as carbon source, and the reference medium containing glucose (GLUM) [19,22,32]. Both contained the following salt solution: (per L of medium) $7 \mathrm{~g} \mathrm{KH}_{2} \mathrm{PO}_{4}, 2 \mathrm{~g} \mathrm{Na}_{2} \mathrm{HPO}_{4}$, $1.5 \mathrm{~g} \mathrm{MgSO}_{4} \cdot 7 \mathrm{H}_{2} \mathrm{O}, 0.1 \mathrm{~g} \mathrm{CaCl}_{2} \cdot 2 \mathrm{H}_{2} \mathrm{O}$. In addition, $10 \mathrm{~mL}$ of $1000 \times$ concentrated trace elements solution containing $\left(0.008 \mathrm{~g} \mathrm{FeCl}_{3} \cdot 6 \mathrm{H}_{2} \mathrm{O}, 0.001 \mathrm{~g} \mathrm{ZnSO} \cdot 7 \mathrm{H}_{2} \mathrm{O}, 0.0001 \mathrm{~g} \mathrm{CoSO}_{4} \cdot 7 \mathrm{H}_{2} \mathrm{O}\right.$, $0.0001 \mathrm{~g} \mathrm{CuSO}_{4} \cdot 5 \mathrm{H}_{2} \mathrm{O}, 0.0001 \mathrm{~g} \mathrm{MnSO}_{4} \cdot 5 \mathrm{H}_{2} \mathrm{O}$ per L) and $10 \mathrm{~mL}$ of $1000 \times$ concentrated $\mathrm{FeCl}_{3} \cdot 6 \mathrm{H}_{2} \mathrm{O}$ were added in $700 \mathrm{~mL}$ of demineralized (demi) water. The $\mathrm{pH}$ of the final solution was adjusted to $6.0 \pm 0.05$ by $1 \mathrm{M} \mathrm{NaOH}$ and $1 \mathrm{M} \mathrm{H}_{2} \mathrm{SO}_{4}$. In the case of GLUM, the final solution was mixed with $3.75 \mathrm{~g}$ of yeast extract and glucose solution which was prepared by dissolving $40 \mathrm{~g}$ of glucose in $300 \mathrm{~mL}$ of demi water. In the case of FATM, the 
final solution was mixed with the animal fat emulsion prepared by dissolving $15 \mathrm{~g}$ fat, $1.5 \mathrm{~g}$ Tween 80 and $3.75 \mathrm{~g}$ yeast extract in $300 \mathrm{~mL}$ demi water. The salt solution and FATM was autoclaved at $121^{\circ} \mathrm{C}$ and at 1 bar for $20 \mathrm{~min}$, while trace element, $\mathrm{FeCl}_{3} \cdot 6 \mathrm{H}_{2} \mathrm{O}$ and glucose solutions were filtered sterilized by using $0.2 \mu \mathrm{m}$ cartridge filter (Whatman FP 30/0.2 CA-S).

FATM and GLUM were used in the shake flask experiment, and only FATM was used for preparing mycelium inoculum for bioreactor experiments. Modified FATM was used for bioreactor experiments, using (per L of media) $8 \mathrm{~g}$ fat, $0.8 \mathrm{~g}$ of Tween 80, and $3.75 \mathrm{~g}$ of yeast extract in the batch experiments, while the fed-batch FATM contained salt solution mixed with $60 \mathrm{~mL}$ of $1000 \times$ concentrated trace elements solution, $60 \mathrm{~mL}$ of $1000 \times$ concentrated $\mathrm{FeCl}_{3} \cdot 6 \mathrm{H}_{2} \mathrm{O}$ and animal fat emulsion, prepared by sonication (Julabo, ISY AS, Norway), comprising of $40 \mathrm{~g}$ fat, $4 \mathrm{~g}$ Tween 80 and $10 \mathrm{~g}$ yeast extract. FATM was steam sterilized in the reactor at $121^{\circ} \mathrm{C}$ for $20 \mathrm{~min}$.

Mycelium inoculum was prepared in two shake flask cultivations. For the first shake flask cultivation, $50 \mathrm{~mL}$ of FATM was inoculated with $0.4 \mathrm{~mL}$ of spore inoculum, incubated for $48 \mathrm{~h}$ at $25.0 \pm 0.1^{\circ} \mathrm{C}$ for M. alpina and for $24 \mathrm{~h}$ at $28.0 \pm 0.1^{\circ} \mathrm{C}$ for $M$. circinelloides in a gyratory shaker with at $180 \mathrm{rpm}$ agitation. For the second shake flask cultivation, $4 \mathrm{~mL}$ of mycelium suspension from the first cultivation was inoculated into $300 \mathrm{~mL}$ of FATM and incubated for $24 \mathrm{~h}$ at the same temperature and agitation. The resulting mycelium suspension was used as inoculum for bioreactor cultivations and accounted for approximately $5 \%$ $(v / v)$ of starting volume in the bioreactor.

\subsection{Shake Flask (SF) Cultivations}

In each experiment, ten to twelve $300 \mathrm{~mL}$ shake flasks were prepared containing $50 \mathrm{~g}$ of FATM or GLUM and inoculated with $0.4 \mathrm{~mL}$ biomass from a first shake flask as described above. Cultivation was carried out at $180 \mathrm{rpm}$ and $25.0 \pm 0.1^{\circ} \mathrm{C}$ for M. alpina and $28.0 \pm 0.1^{\circ} \mathrm{C}$ for $M$. circinelloides. The biomass from 2 shake flasks per day were collected and processed further to obtain wet cell weight, dry cell weight, fatty acid profile, and total lipid content. Each shake flask represents a sample point in the results.

\subsection{Bioreactor Cultivations}

The submerged fermentation experiments for $M$. circinelloides and $M$. alpina were performed in $15 \mathrm{~L}$ turbine-stirred bioreactor (Chemap, Switzerland) equipped with three Rushton turbines which can be operated at a maximum stirrer speed of $800 \mathrm{rpm}$. The batch experiments were performed with $8.0 \mathrm{~L}$ of media, whereas during fed-batch experiments the starting volume was 6.0 L. During the cultivation the temperature was kept constant at $25 \pm 0.1{ }^{\circ} \mathrm{C}$ or $28.0 \pm 0.1{ }^{\circ} \mathrm{C}$ depending on the fungal strain. A pH meter (Mettler Toledo InPro ${ }^{\circledR} 3030 / 120$ ) was used to maintain the pH at $6.0 \pm 0.05$ with $1 \mathrm{M} \mathrm{NaOH}$ and $1 \mathrm{M} \mathrm{H}_{2} \mathrm{SO}_{4}$. The aeration rate was maintained at $0.3 \mathrm{vvm}$ via a mass-flow controller (Brooks 58505 calibration at $0{ }^{\circ} \mathrm{C}$ and 1 bar) by supplying a sterile air through the bottom sparger. The reactor was operated at an overpressure of 0.3 bar to facilitate rapid removal of sample and to avoid blockage of the sampling ports. Dissolved oxygen was maintained at minimum of $30 \%$ of air saturation by regulating the stirrer speed during cultivation. The exhaust gas of the fermenter was cooled with a condenser connected to tap water supply filtered by $0.2 \mu \mathrm{m}$ PTFE membrane (PALL Corporation) before online analysis of the $\mathrm{CO}_{2}$ and $\mathrm{O}_{2}$ volume fractions using an inbuilt analyzer-exhalyzer-in BioEngineering fermenter (BioEngineering, Switzerland). Online data acquisition was carried out using LabVIEW software. One experiment, batch and fed-batch, per fungal strain was performed. Glanapon 2000 was used as antifoam in all experiments.

In the batch fermentation, the batch phase started at $\mathrm{t}=0 \mathrm{~h}$ by inoculating the media with $500 \mathrm{~mL}$ of mycelium inoculum. The fermenter was aerated at $2.5 \mathrm{~L} / \mathrm{min}$ with an overpressure of 0.3 bar. Dissolved oxygen was maintained at minimum $30 \%$ of air saturation by regulating the agitator speed and air flow. When the off-gas $\mathrm{CO}_{2}$ concentration in the fermenter dropped, the batch phase was considered over. 
In the fed-batch fermentation, the batch phase was carried out using 6.0 L of FATM inoculated with $300 \mathrm{~mL}$ of mycelium inoculum. The batch phase cultivation conditions were as described above. The fed-batch media was sterilized before addition to the fermenter, stirred continuously and kept warm using a heating plate to avoid solidification of fat in the media. After completion of the batch phase, the fed-batch medium was fed to the fermenter with an exponential feed profile controlled using peristaltic pump, until the broth mass in the fermenter reached a volume of approximately $8.0 \mathrm{~L}$.

\subsection{Sampling and Analytical Procedures}

During the fermentations, $35 \mathrm{~mL}$ samples were collected at regular interval. Each sample was divided into three parts ( $5 \mathrm{~mL}$ per tube in duplicates) for: (1) quantification of wet cell weight, (2) dry cell weight, and (3) collection of supernatant and biomass pellet.

For the wet cell weight measurement, cell culture samples were first, centrifuged (Labofuge 200, Heraeus Sepatech, Kendo Laboratory Product, San Francisco, CA, USA) at $3000 \times g$ for $15 \mathrm{~min}$. The supernatant was then collected and stored at $-20^{\circ} \mathrm{C}$ for further analysis, whereas the obtained cell pellet was weighed, and wet cell weight estimated.

For the dry cell weight measurement, cell culture samples were washed by repeating the following procedure. The samples were first centrifuged (Labofuge 200, Heraeus Sepatech, Kendo Laboratory Product) at $3000 \times g$ for $15 \mathrm{~min}$. After discarding the supernatant, the obtained cell pellet was resuspended in $5 \mathrm{~mL}$ of deionized water. This procedure was repeated once more, after which the samples were ready for measurement. Total of $5 \mathrm{~mL}$ of the sample, obtained after washing procedure, was filtered using dried and pre-weighed $1.0 \mu \mathrm{m}$ pore diameter glass fiber filter paper (Type A/E, Pall Life Sciences, New York, NY, USA). The filter with cell mass was washed with deionized water, dried at $70{ }^{\circ} \mathrm{C}$ for $24 \mathrm{~h}$, and weighed to yield dry cell weight.

For collection of biomass and supernatant, the procedure for dry cell weight determination was followed, except the biomass pellet obtained on filter was collected and stored in a cryotube at $-20^{\circ} \mathrm{C}$.

\subsection{Determination of Lipid Content and Fatty Acid (FA) Composition of Biomass}

Determination of lipid content and fatty acid composition of fungal biomass was performed by direct transesterification method according to Lewis et al. [33] with modifications [34]. Approx. $20 \mathrm{mg}$ of the freeze-dried biomass was weighed and transferred to a 2 $\mathrm{mL}$ polypropylene (PP) tube containing approx. $250 \mathrm{mg}$ acid washed glass beads. Total of $500 \mu \mathrm{L}$ chloroform and $1 \mathrm{mg}$ of internal standard in $100 \mu \mathrm{L}$ hexane (glyceryl tridecanoate $\left(\mathrm{C}_{42} \mathrm{H}_{80} \mathrm{O}_{6}, \mathrm{C} 13: 0\right.$ TAG (13:0/13:0/13:0), Sigma-Aldrich, St. Louis, MO, USA) were added to the PP tube. The biomass was homogenized by bead beating in a homogenizer at $5500 \mathrm{rpm}$ for $20 \mathrm{~s}$ cycle length and 6 cycles (Precellys Evolution Tissue homogenizer, Bertin Instruments, Montigny-le-Bretonneux, France). The mixture was transferred to a clean glass tube by washing the PP-tube with $2400 \mu \mathrm{L}$ of methanol:hydrochloric acid:chloroform solution $(7.6: 1: 1 v / v)$. Finally, $500 \mu \mathrm{L}$ methanol was added to the glass tube. The mixture was then vortexed and incubated at $90{ }^{\circ} \mathrm{C}$ for $90 \mathrm{~min}$ in a heating block. After cooling to room temperature, $1 \mathrm{~mL}$ deionized water was added to the glass tube. The fatty acid methyl esters (FAMEs) were extracted by the addition of $2 \mathrm{~mL}$ hexane, followed by $10 \mathrm{~s}$ vortex mixing. The tube was centrifuged for $5 \mathrm{~min}$ at $3000 \mathrm{rpm}$ and at $4{ }^{\circ} \mathrm{C}$, and the upper (organic) phase was transferred to a clean glass tube. The lower (water) phase was extracted two more times, but now by the addition of $2 \mathrm{~mL}$ hexane:chloroform mixture (4:1 $v / v)$. After solvent evaporation under $\mathrm{N}_{2}$-flow, $1500 \mu \mathrm{L}$ hexane containing $0.01 \%$ butylated hydroxytoluene (BHT) was added together with anhydrous $\mathrm{Na}_{2} \mathrm{SO}_{4}$-salt. The solution was then transferred to a gas chromatography vial and analyzed by gas chromatography.

Gas chromatography was performed by using gas chromatograph 7820A (Agilent Technologies, Santa Clara, CA, USA), equipped with an Agilent J\&W 121-2323 DB-23 column $(20 \mathrm{~m} \times 180 \mu \mathrm{m} \times 0.20 \mu \mathrm{m})$, and a flame ionization detector (FID). Helium was used as a carrier gas. The total runtime for each sample was $36 \mathrm{~min}$ with the following 
oven temperature increase: initial temperature $70{ }^{\circ} \mathrm{C}$ for $2 \mathrm{~min}$, after $8 \mathrm{~min}$ to $150{ }^{\circ} \mathrm{C}$ with no hold time, $230{ }^{\circ} \mathrm{C}$ in 16 min with 5 min hold time, and $245^{\circ} \mathrm{C}$ in $1 \mathrm{~min}$ with 4 min hold time. The injector temperature was $250^{\circ} \mathrm{C}$ and $1 \mu \mathrm{L}$ of a sample was injected (30:1 split ratio, with split flow $30 \mathrm{~mL} / \mathrm{min}$ ). For the identification and quantification of fatty acids, the Supelco 37 Component FAME Mix (C4-C24 FAME mixture, Sigma-Aldrich) was used as an external standard, in addition to C13:0 TAG internal standard. Measurements were controlled by the Agilent OpenLAB software (Agilent Technologies).

\subsection{Determination of Lipid Content in Emulsion}

The initial emulsions and supernatants were thoroughly mixed by ultrasound homogenization. The samples were sonicated for $30 \mathrm{~s}$ by an ultrasonic probe coupled to an ultrasonic processor (Vibra-Cell VC505, Sonics and materials, Inc., Newtown, CT, USA) under $100 \%$ power. About $0.5-1 \mathrm{~mL}$ of the suspension (depending on the estimated fat concentration) was pipetted into pre-weighed glass tubes, frozen and then freeze dried for $72 \mathrm{~h}$ at $-52{ }^{\circ} \mathrm{C}$. The glass tube containing the freeze-dried media was weighed, followed by an aforementioned direct transesterification and GC-analysis (excluding the bead beating homogenization step). Lipid content of the freeze-dried material was determined, and the concentration of fat $(\mathrm{g} / \mathrm{L})$ in the starting emulsions and supernatants was calculated based on the dry weight values.

The error bars, indicated in Figures, were calculated based on duplicate samples collected for dry cell weight and lipid analysis during experimentation. The data presented in Figures 4, 6, and 9 were based on single analysis and hence did not contain error bars.

\section{Results}

To develop a fermentation process for converting animal fat rest materials into unsaturated single cell oil by $M$. circinelloides and M. alpina, shake flask cultivations were first performed, followed by the batch and fed-batch fermentations.

\subsection{Shake Flask Cultivations}

The shake flask cultivations of $M$. circinelloides and $M$. alpina strains were performed by using glucose and animal fat rest materials as carbon source. First, the cultivations were performed for $120 \mathrm{~h}$ or $145 \mathrm{~h}$ by using glucose $(40 \mathrm{~g} / \mathrm{L})$ as a carbon source. The obtained final biomass concentrations ( $\mathrm{g}$ DCW/L) for $M$. circinelloides and $M$. alpina were $10.1 \pm 2.5$ and $11.2 \pm 0.5$, respectively (Figure 1). M. circinelloides reached stationary phase after $42 \mathrm{~h}$ with a final lipid content of $50.1 \% \%_{\mathrm{wt}}$ (of dry cell weight), while $M$. alpina showed slower growth with the stationary phase observed after $120 \mathrm{~h}$ and a final lipid content of $54.6 \%_{\mathrm{wt}}$ (Figure 2). The formation of linoleic acid and gamma-linolenic acid (GLA) was found in M. circinelloides. Linoleic acid showed an increase whereas GLA content remained same during the growth of $M$. circinelloides. Production of arachidonic acid (ARA) was observed only in M. alpina, with the final obtained ARA content of $40.1 \%_{\mathrm{wt}}$ (of total lipid weight).

The shake flask cultivations with animal fat rest materials $(15 \mathrm{~g} / \mathrm{L})$ were conducted for $120 \mathrm{~h}$ in the case of $M$. circinelloides and $170 \mathrm{~h}$ for $M$. alpina. The results indicate that both strains can grow on animal fat as the sole carbon source (Figure 3). M. circinelloides cultivated on animal fat showed a similar growth trend as on glucose, but with slightly higher biomass concentration and total lipid content (Figure 4). The final biomass concentration and lipid content for $M$. circinelloides were $16.7 \pm 2.2 \mathrm{~g}$ DCW $/ \mathrm{L}$ and $54.1 \%_{\mathrm{wt}}$ (Figure 4A). However, the linoleic acid and GLA content dropped almost by half for fatgrown $M$. circinelloides compared to grown on glucose. Figure 3B shows that $M$. alpina grew slower on animal fat and had a longer lag phase. The final biomass concentration $(6.4 \pm 0.9 \mathrm{~g} \mathrm{DCW} / \mathrm{L})$ and arachidonic acid content $\left(19.7 \%_{\mathrm{wt}}\right)$ for M. alpina grown on animal fat were significantly lower than for the cultivation on glucose (Figures 3B and 4B). However, total lipid content was quite similar for both substrates: $52.7 \%{ }_{\mathrm{wt}}$ for cultivation on animal fat, compared to $54.6 \%{ }_{\mathrm{wt}}$ on glucose (Figures $2 \mathrm{~B}$ and $4 \mathrm{~B}$ ). 

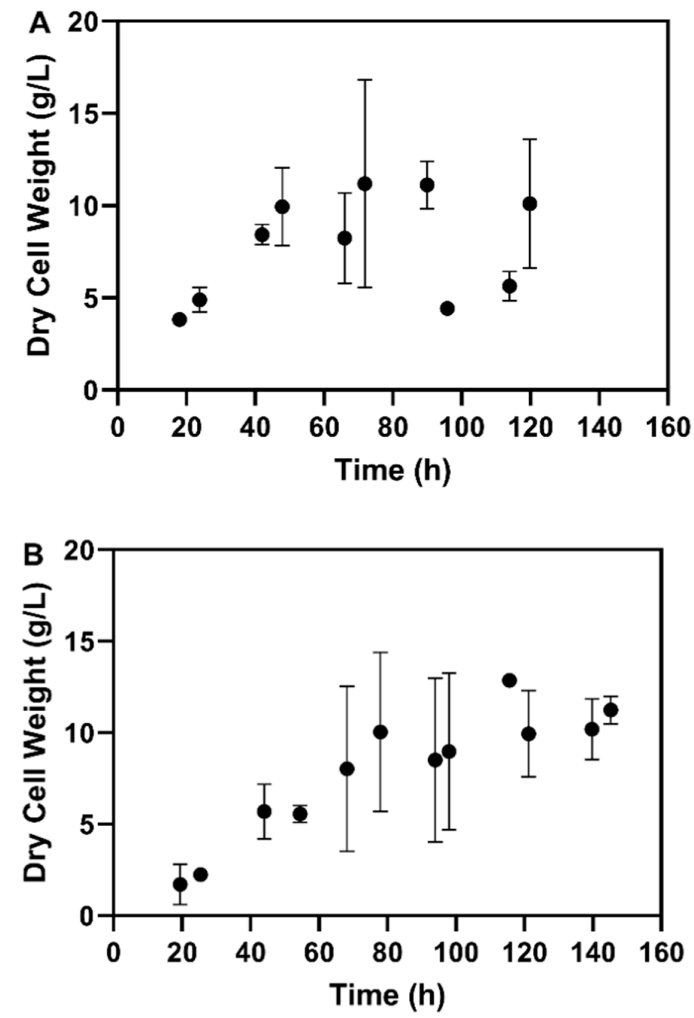

Figure 1. Growth curve profiles for: (A) M. circinelloides, and (B) M. alpina, grown on glucose in shake flasks.
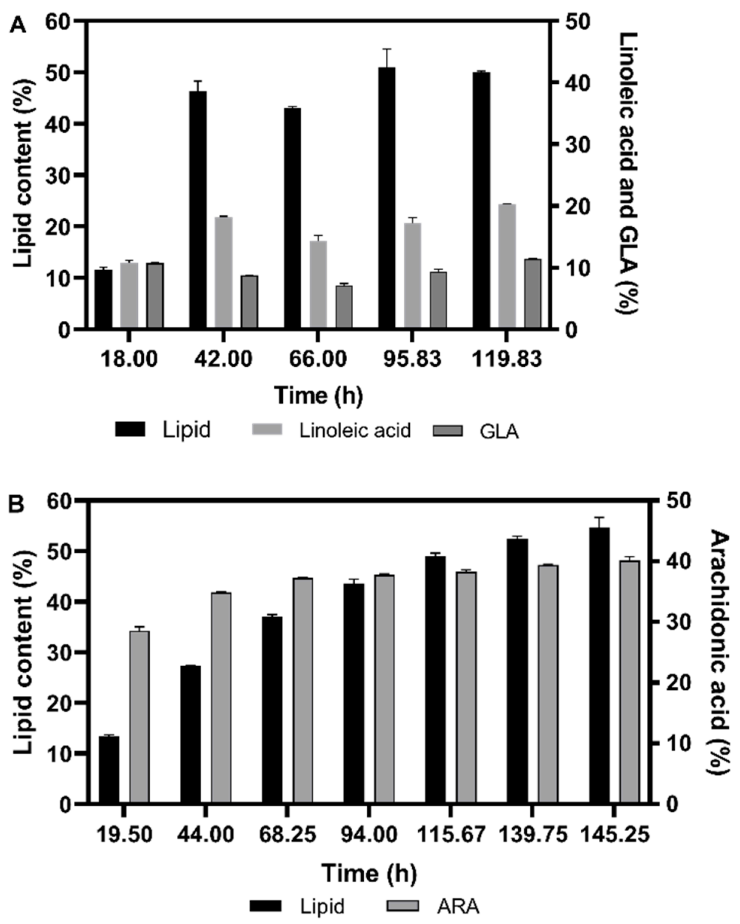

Figure 2. (A) Total lipid content ( $\%_{\mathrm{wt}}$ of dry cell weight), linoleic acid, and GLA ( $\%_{\mathrm{wt}}$ of total lipid weight) for M. circinelloides, and (B) total lipid content ( $\%{ }_{\mathrm{Wt}}$ of dry cell weight) and arachidonic acid (ARA) content ( $\%_{\mathrm{wt}}$ of total lipid weight) for M. alpina, grown on glucose in shake flasks. 

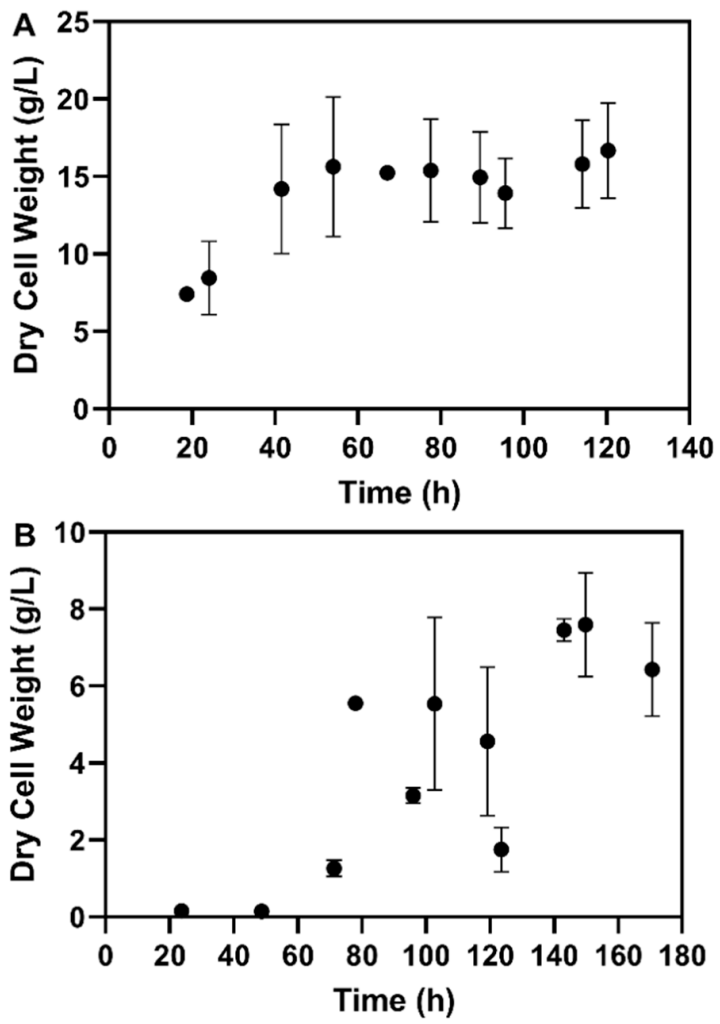

Figure 3. Growth curve profiles for (A) M. circinelloides, and (B) M. alpina, grown on animal fat by-product materials.
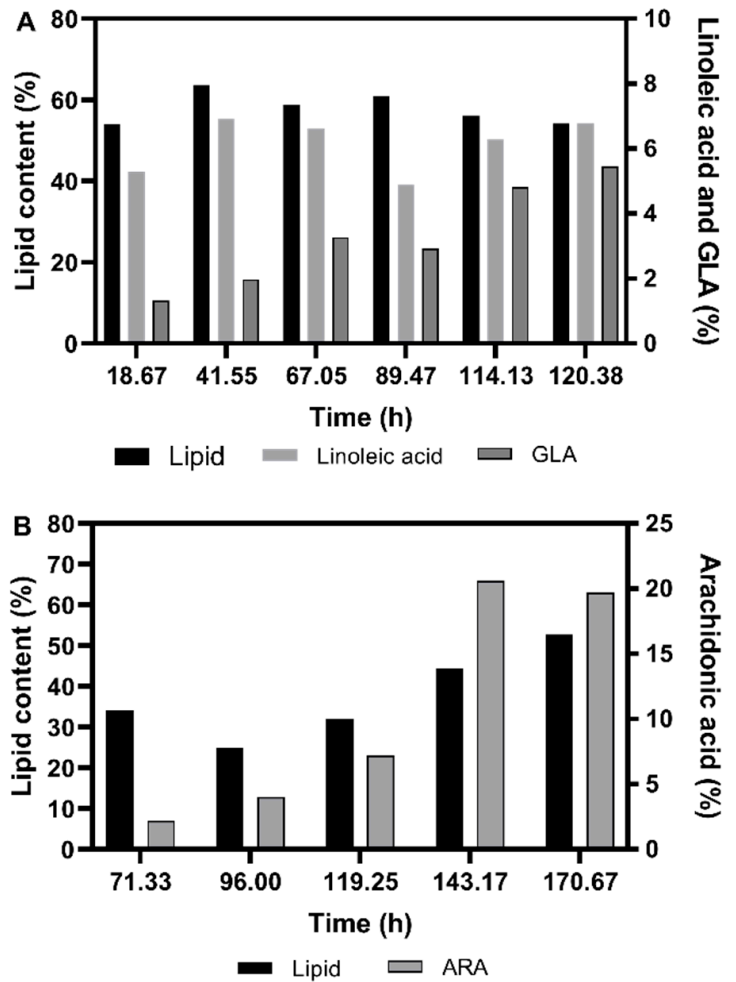

Figure 4. (A) Total lipid content ( $\%_{\mathrm{wt}}$ of dry cell weight), linoleic acid, and GLA ( $\%_{\mathrm{wt}}$ of total lipid weight) for $M$. circinelloides, and (B) total lipid content $\left(\%_{\mathrm{wt}}\right.$ of dry cell weight) and arachidonic acid (ARA) content $\left(\%_{\mathrm{wt}}\right.$ of total lipid weight) for M. alpina, grown on animal fat rest materials in shake flasks. 


\subsection{Fermentation Experiments Using Animal Fat By-Product Materials as C-Source}

The effect of controlled parameters on the growth and lipid formation in oleaginous M. circinelloides and M. alpina using animal fat by-product materials as a substrate was investigated by carrying out batch and fed-batch fermentations. The growth profiles of M. circinelloides and M. alpina were determined by performing the batch cultivation of each organism in $15 \mathrm{~L}$ fermenters with $8.5 \mathrm{~L}$ of broth medium and using the animal fat byproduct materials as a substrate $(15 \mathrm{~g} / \mathrm{L})$. The dissolved $\mathrm{O}_{2}$ in the medium was maintained above $30 \%$ by varying the agitation speed and aeration. An overpressure of 0.3 bar was maintained in the fermenter to facilitate sampling, reduce the risk of contamination, and increase $\mathrm{O}_{2}$ solubility in the medium. The growth of strains in fermenters was monitored based on real time off-gas $\mathrm{CO}_{2}$ profile.

A lag phase of around $13 \mathrm{~h}$ was identified during the batch growth of $M$. circinelloides, which was not recorded in shake flask cultivations due to the absence of sampling (Figure 5A). During the batch fermentation, the dissolved $\mathrm{O}_{2}$ concentration was maintained only by gradually increasing the agitation speed from 150 to $350 \mathrm{rpm}$. After $10 \mathrm{~h}$ of cultivation, the off-gas $\mathrm{CO}_{2}$ dropped and stabilized after $13 \mathrm{~h}$, however, the cells were still growing. Due to the formation of uncontrolled cream (i.e., mixture of cells, fat, and foam) on the top of the culture in the fermenter after $26 \mathrm{~h}$ of cultivation, the batch fermentation experiment was terminated after $32 \mathrm{~h}$. During this period the animal fat substrate was not consumed completely. The total lipid content in the Mucor biomass showed the similar trend found in the fat-based shake flask experiment and was constant after $21 \mathrm{~h}$ of the cultivation (Figure 5C). The linoleic acid and GLA also showed similar content as achieved in shake flask experiment (Figure 4A). The biomass concentration of $8.7 \pm 1.5 \mathrm{~g}$ DCW/L and total lipid content of $45.6 \%_{\mathrm{wt}}$ were obtained at the end of $M$. circinelloides batch fermentation.

M. alpina strain showed slow growth on animal fat by-product materials during the batch cultivation in fermenter (Figure 6A) and displayed a $20 \mathrm{~h}$ of lag phase. In this experiment, the dissolved $\mathrm{O}_{2}$ concentration in the broth was maintained above $30 \%$ solely by varying the agitation speed (150-250 rpm). The $\mathrm{CO}_{2}$ concentration in off-gas dropped after $35 \mathrm{~h}$ and remained stable after $50 \mathrm{~h}$. No cream formation was observed during this experiment and batch cultivation was stopped after $76 \mathrm{~h}$ based on off-gas $\mathrm{CO}_{2}$ concentration. The higher lipid content obtained at the initial stage of the fermentation experiment might be due to the sampling error, however it remained constant after $32 \mathrm{~h}$ (Figure 6C). The formation of arachidonic acid increased over time. The final biomass concentration, biomass lipid content, and arachidonic acid content were $5.3 \pm 0.2 \mathrm{~g} \mathrm{DCW} / \mathrm{L}$, $34.3 \%_{\mathrm{wt}}$, and $6.1 \%_{\mathrm{wt}}$, respectively.

\subsubsection{Fed-Batch Cultivation}

The effect of different mode of fermenter operation on cell growth and lipid formation was investigated by performing fed-cultivation of M. circinelloides and M. alpina strains. In the batch phase cultivation of both organisms, the animal fat concentration used was $8.0 \mathrm{~g} / \mathrm{L}$ with starting broth volume of $6.3 \mathrm{~L}$. For the M. circinelloides strain, the batch phase was considered to be finished at $26 \mathrm{~h}$ based on off-gas $\mathrm{CO}_{2}$ concentration, followed by the start of the fed-batch phase (indicated by dotted vertical line in Figure 7A,B). The lag phase of $13 \mathrm{~h}$ was observed, and at the end of the batch phase a low biomass concentration of only $2.1 \pm 0.2 \mathrm{~g}$ DCW/L was achieved. The exponential feeding of the substrate was applied during the feed phase, with an aim to achieve the growth rate of $0.09 \mathrm{~h}^{-1}$. The increasing trend of biomass was observed during the initial feed phase. However, the uncontrolled cream formation started after $32 \mathrm{~h}$ with observable decrease in biomass concentration. The fermentation experiment was stopped after $37 \mathrm{~h}$. The total lipid content of the biomass varied from 24 to $40 \%_{\mathrm{wt}}$ during the whole fermentation, ending with $28.4 \%_{\mathrm{wt}}$ at $37 \mathrm{~h}$. The linoleic acid and GLA showed the similar content that observed in batch fermentation. 

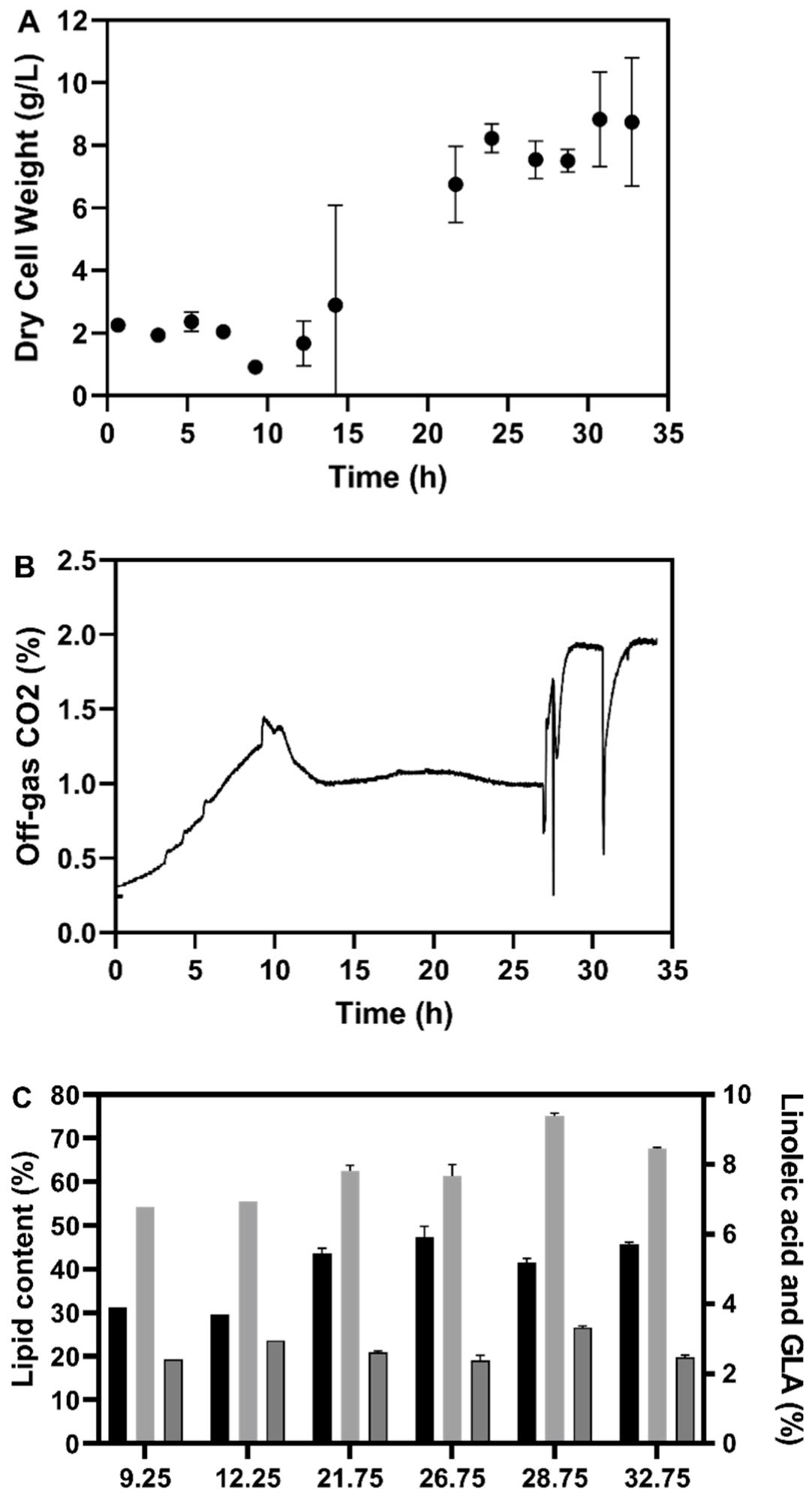

Time (h)

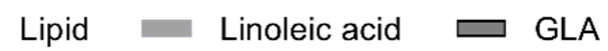

Figure 5. (A) Dry cell weight (DCW), (B) off-gas $\mathrm{CO}_{2}$ profile, and (C) total lipid content (\% $\%_{\mathrm{wt}}$ of dry cell weight), linoleic acid, and GLA ( $\%_{\mathrm{wt}}$ of total lipid weight) obtained during batch cultivation of M. circinelloides in fermenter using animal fat rest materials. 

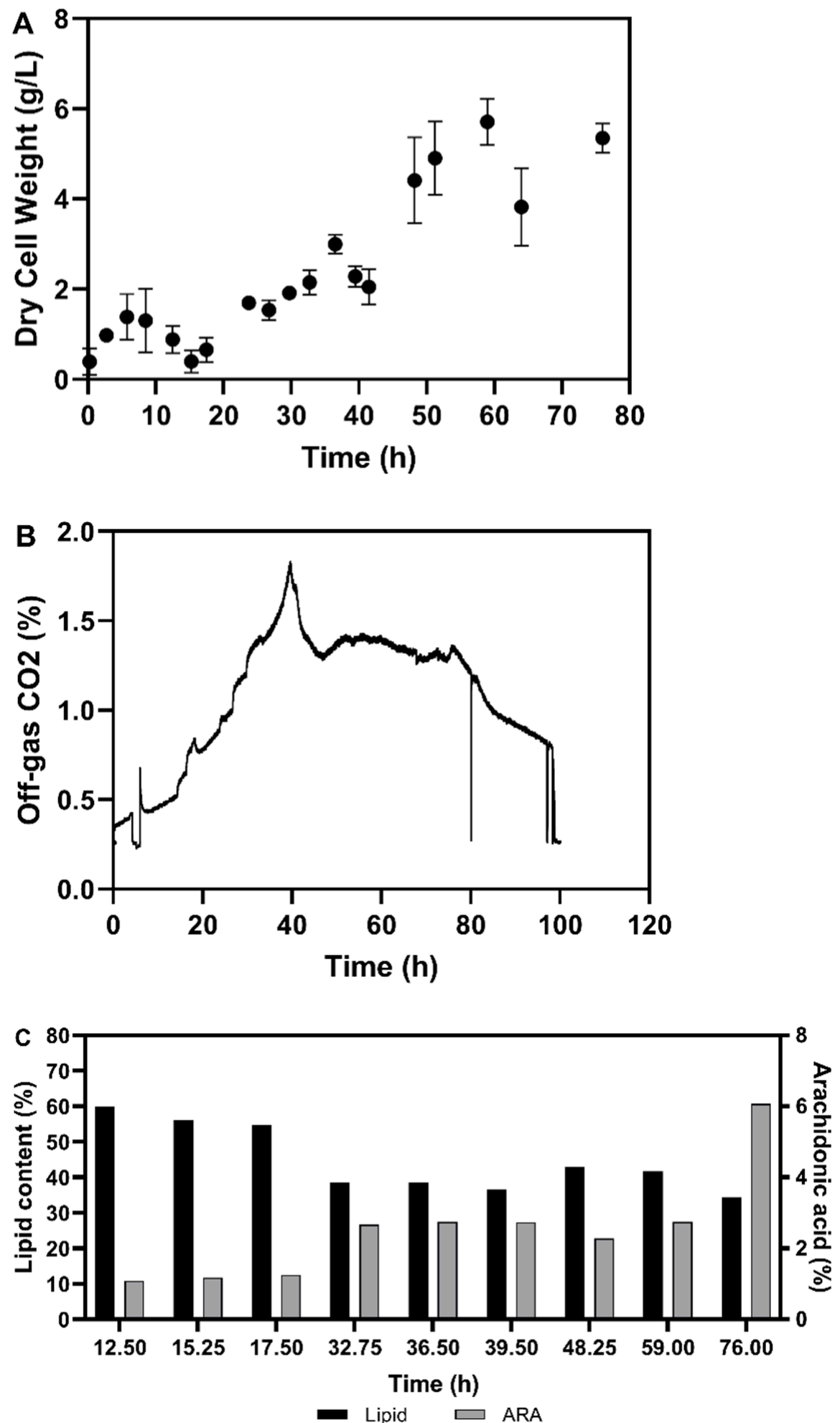

Figure 6. (A) Dry cell weight (DCW), (B) off-gas $\mathrm{CO}_{2}$ profile, (C) total lipid content $(\%$ wt of dry cell weight) and arachidonic acid (ARA) content ( $\%_{\mathrm{wt}}$ of total lipid weight) obtained during the batch cultivation of M. alpina in fermenter using animal fat rest materials. 

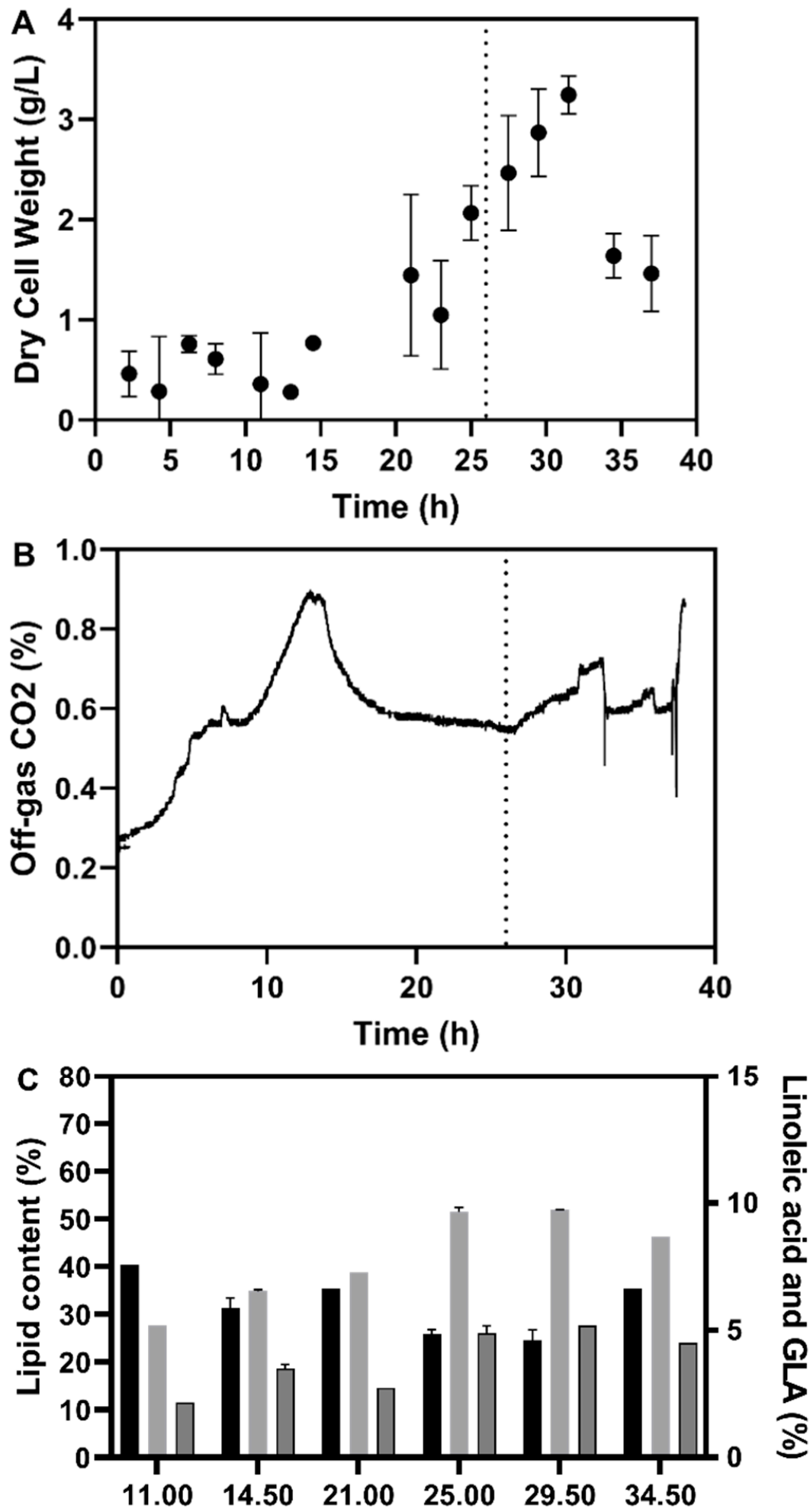

Time (h)

\section{Lipid $\square$ Linoleic acid $\square$ GLA}

Figure 7. (A) Dry cell weight, (B) off-gas $\mathrm{CO}_{2}$ profile, and (C) total lipid content $(\%$ wt of dry cell weight), linoleic acid, and GLA ( $\%_{\mathrm{wt}}$ of total lipid weight) obtained during fed-batch cultivation of M. circinelloides in fermenter using animal fat rest materials. The dotted vertical line indicates the beginning of feed phase. 
In the fed-batch cultivation of M. alpina, the batch phase was completed at $54 \mathrm{~h}$ based on $\mathrm{CO}_{2}$ concentration in off-gas profile. The obtained biomass concentration was $8.3 \pm 0.3 \mathrm{~g} \mathrm{DCW} / \mathrm{L}$ (Figure 8A). The feed phase started with the exponential feeding of the animal fat to maintain the growth rate of $0.025 \mathrm{~h}^{-1}$. The cell growth profile showed biomass concentration increased (up to $12.4 \pm 0.8 \mathrm{~g}$ DCW/L) until $102 \mathrm{~h}$ of cultivation and then decreased even though the feeding was continued. The experiment was stopped after $130 \mathrm{~h}$ as the feeding was finished. During the experiment, the lipid content of the biomass varied between 31 and $60 \%_{\mathrm{wt}}$, whereas the formation of arachidonic acid has increased over time following the feeding profile of the experiment (Figure 8C). The lipid content of the biomass and arachidonic acid content in the lipids, achieved at the end of the experiment, was $55.8 \%_{\mathrm{wt}}$ and $23.8 \%_{\mathrm{wt}}$, respectively.
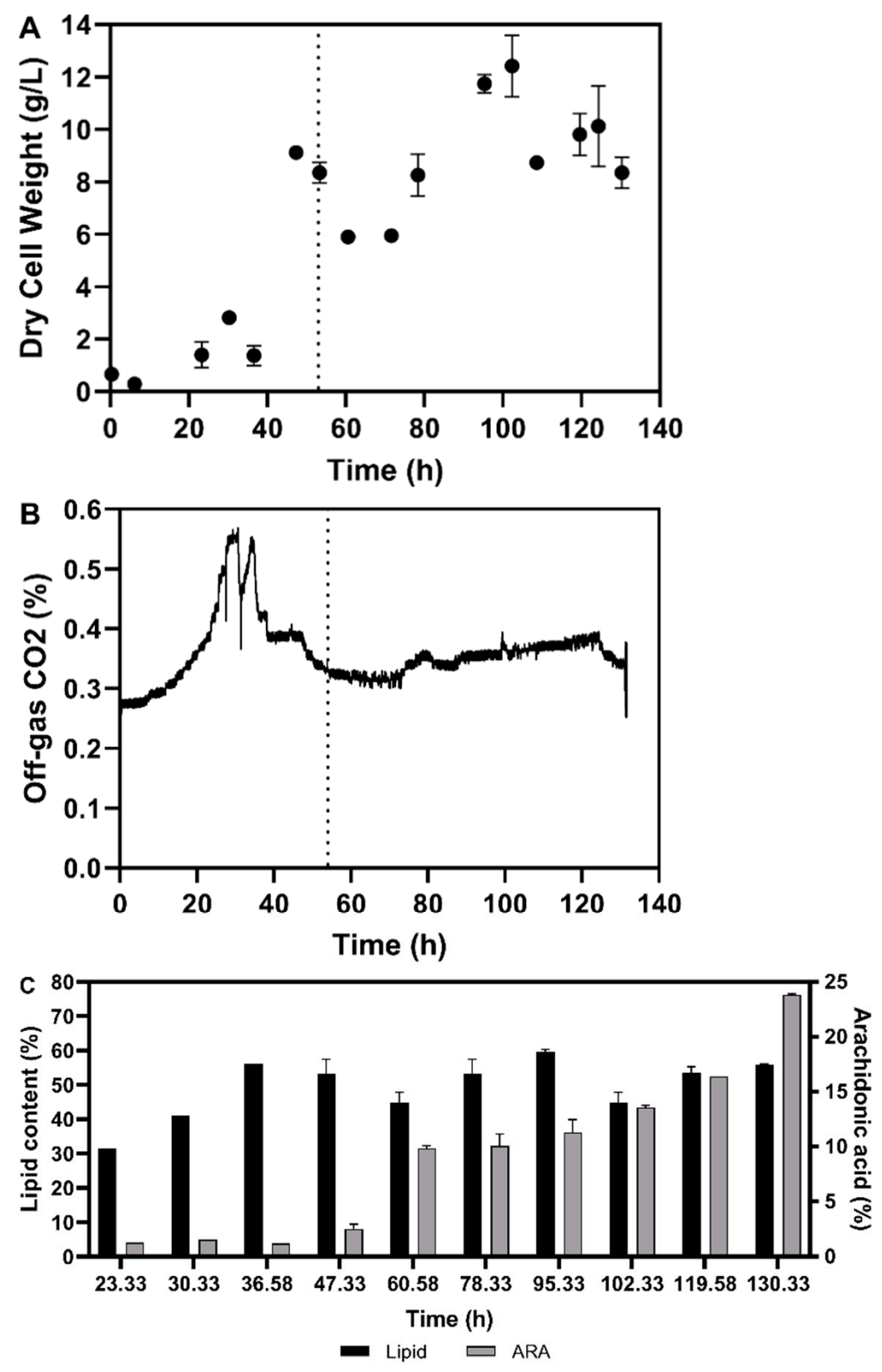

Figure 8. (A) Dry cell weight, (B) off-gas $\mathrm{CO}_{2}$ profile, and (C) total lipid content $\left(\%_{\mathrm{wt}}\right.$ of dry cell weight) and arachidonic acid (ARA) content ( $\%_{\mathrm{wt}}$ of total lipid weight) obtained during fed-batch cultivation of M. alpina in fermenter using animal fat waste. The dotted vertical line indicates the beginning of feed phase. 


\subsubsection{Fatty Acid Composition of the Single Cell Oil}

The fatty acid composition of M. circinelloides and M. alpina SCO, obtained during different modes of cultivation using animal fat rest materials as substrate, is listed in Tables 1 and 2, respectively. The M. circinelloides SCO is characterized by the presence of a series of saturated (C14:0, C16:0, C17:0, C18:0) and monounsaturated (C16:1n5, C17:1, $\mathrm{C} 18: 1 \mathrm{n} 9 \mathrm{c}$ ) (Table 1) fatty acids and polyunsaturated fatty acids are represented only by gamma-linolenic acid (GLA, C18:3n6), whereas in M. alpina SCO the presence of GLA and arachidonic acid (ARA, C20:4n6) was found and dominated over the saturated and monounsaturated fatty acids (Table 2). These results are in agreement with the ones reported previously by Kosa et al., 2018 [32] and Dzurendova et al., 2020 [21] for fermentations in glucose media.

Table 1. Fatty acid composition ( $\%_{\mathrm{wt}}$ of total lipid weight) for M. circinelloides single cell oil obtained from cultivation on animal fat rest materials.

\begin{tabular}{ccccccccccccccc}
\hline & & Time (h) & C14:0 & C16:0 & C16:1 & C17:0 & C18:0 & C18:1n9c & C18:2n6c & C18:3n6 & C18:3n3 & Other & Total Lipid Content (wt\%) \\
\hline SF & $50 \mathrm{~mL}$ & 120.38 & 0.50 & 19.87 & 0.95 & 1.18 & 29.28 & 32.04 & 6.77 & 5.45 & 0.00 & 3.96 & 54.14 & \\
\hline Batch & $8.5 \mathrm{~L}$ & 32.75 & 1.17 & 21.12 & 1.81 & 0.82 & 17.47 & 43.23 & 8.46 & 2.48 & 0.69 & 2.75 & 45.61 & \\
\hline Fed-batch & $8.0 \mathrm{~L}$ & 34.5 & 1.71 & 22.69 & 2.35 & 0.92 & 15.98 & 38.54 & 8.68 & 4.51 & 0.83 & 3.78 & 28.44 & \\
\hline
\end{tabular}

Table 2. Fatty acid composition ( $\%_{\mathrm{wt}}$ of total lipid weight) for M. alpina single cell oil obtained from cultivation on animal fat rest materials.

\begin{tabular}{ccccccccccccccccc}
\hline & & Time (h) & C14:0 & C16:0 & C16:1 & C18:0 & C18:1n9c & C18:2n6c & C18:3n6 & C18:3n3 & C20:3n6 & C20:4n6 & C24:0 & Other & Total Lipid Content (wt\%) \\
\hline SF & $50 \mathrm{~mL}$ & 170.67 & 1.58 & 18.91 & 1.73 & 16.46 & 25.80 & 5.24 & 2.48 & 0.55 & 0.00 & 19.72 & 1.42 & 6.11 & 52.67 & \\
\hline Batch & $8.5 \mathrm{~L}$ & 76 & 2.02 & 21.01 & 2.53 & 14.31 & 36.95 & 6.21 & 4.49 & 0.85 & 0.54 & 6.07 & 0.58 & 4.43 & 34.27 & \\
\hline Fed-batch & $8.0 \mathrm{~L}$ & 130.33 & 1.41 & 16.54 & 1.64 & 12.15 & 27.02 & 5.32 & 2.77 & 0.59 & 1.50 & 23.80 & 0.75 & 4.68 & 55.77 & \\
\hline
\end{tabular}

Different cultivation approaches used in the study resulted in a M. circinelloides SCO of a similar fatty acid composition. Regarding M. alpina SCOs, the GLA composition was comparable after the shake flask cultivation and the fed-batch fermenter fermentation. However, these values were almost half of the amount obtained during batch fermentation in fermenter. In contrast, ARA content was higher after the shake flask cultivation and fed-batch fermentation, compared to the ARA content after the batch fermentation. Other fatty acid components in the M. alpina SCOs were comparable for all the three types of cultivation.

The comparison of biomass concentration, total lipid content, and high-value unsaturated fatty acids (GLA + ARA) content achieved at the end of SF experiment, batch and fed-batch fermentations for M. circinelloides and M. alpina are shown in Figure 9. In the case of $M$. circinelloides cultivation, all the parameters are the highest for shake flask cultivation, lower for batch and the lowest in fed-batch fermentations. To a certain extent this was due to the incomplete batch and fed-batch experiments caused by the cream formation. M. alpina showed comparable biomass production for shake flask cultivation and batch fermenter cultivation, while lipid and unsaturated fatty acid content were higher in shake flasks than in batch cultivations. The highest production parameters were obtained in fed-batch fermentation.

\subsection{Discussion}

In this study we investigated the bioconversion of animal fat by-product materials into unsaturated SCO by oleaginous filamentous fungi M. circinelloides and M. alpina. Three types of cultivations-shake flask, batch, and fed-batch fermentations-were performed. In addition, the shake flask cultivations on glucose as a carbon source were carried out for reference. For both strains grown on glucose in the shake flasks, the biomass concentration was lower and lipid content was higher than previously stated by Kosa et al., 2018, 2017 [19,32]. The lipid content of $M$. circinelloides was relatively constant after $42 \mathrm{~h}$ of growth. This was also observed in the previous studies [19,32], indicating the depletion of nitrogen source and the stationary phase of cells. Production of ARA in M. alpina was similar to the previously 
reported results [31,35], whereas the total lipid content increased steadily signifying the slow depletion of nitrogen source which is mainly due to the slow growth of cells.
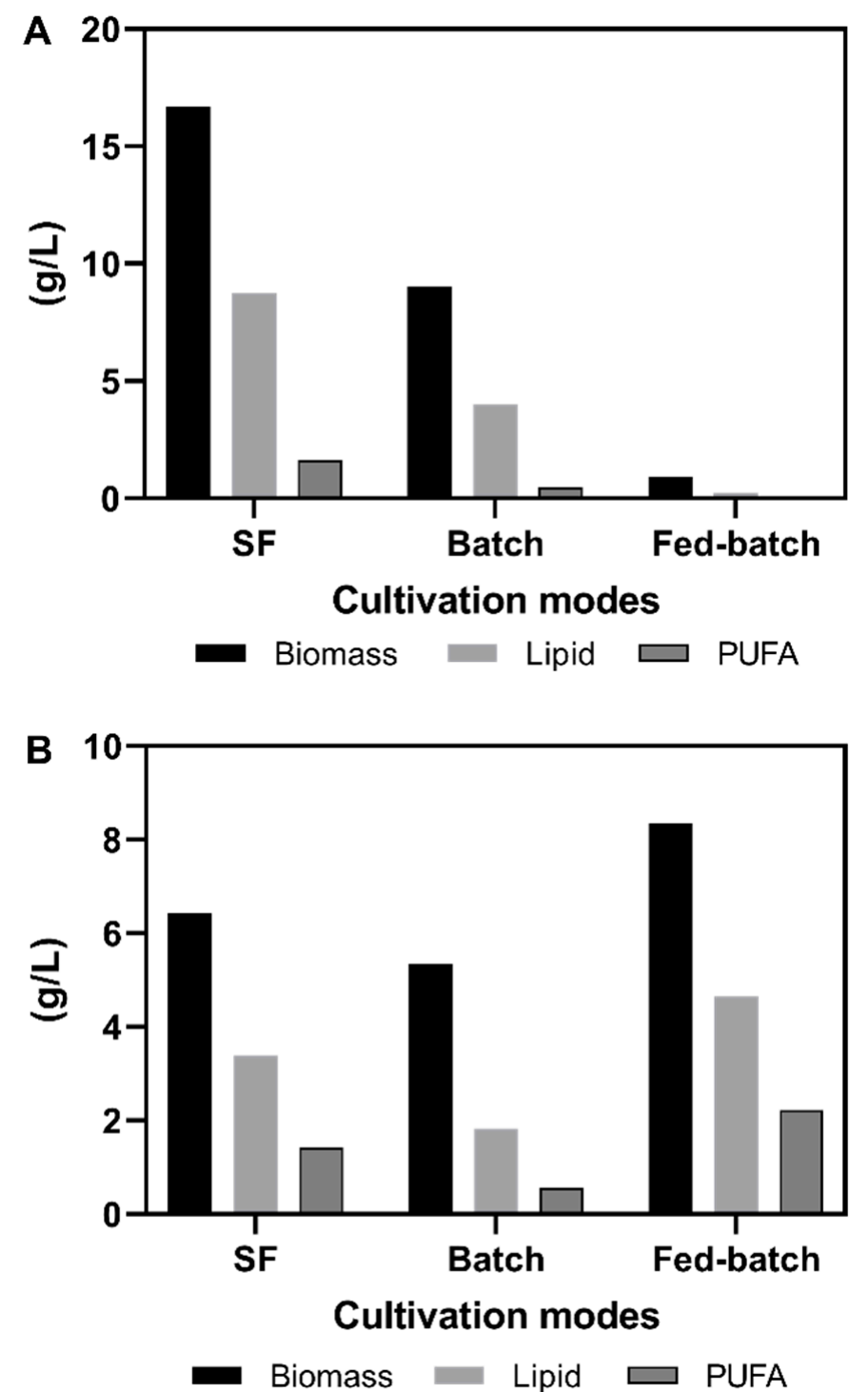

Figure 9. The biomass, total lipid content, and unsaturated fatty acids (GLA + ARA) concentrations obtained at the end of Shake flask (SF) experiment, batch and fed-batch fermentation for M. circinelloides (A) and M. alpina (B).

Cultivation of $M$. circinelloides on animal fat in shake flask resulted in similar biomass concentration, total lipid content, and fatty acid profile as observed for cultivation on glucose. However, M. alpina showed longer lag phase with less biomass formation when grown on animal fat than for cultivation on glucose. The total lipid content for M. alpina follows the growth and was comparable to that obtained when grown on glucose. Thus, it can be concluded that, $M$. alpina and $M$. circinelloides follow a similar lipid formation trend when cultivated on animal fat and on glucose as a substrate.

The formation of cream which consisted of fungal cells, fat, and foam was observed after $26 \mathrm{~h}$ of batch fermentation of $M$. circinelloides on animal fat. The cream raised in the fermenter head space and filled it completely. This might have been caused by the increased agitation speed (from 150-350 rpm) applied to control the dissolved $\mathrm{O}_{2}$ in broth medium above $30 \%$, which resulted in a high shear stress on cells. $M$. circinelloides being a dimorphic fungus, grows in yeast-like single cell form under high shear stress [32], which can facilitate cream generation [36]. Moreover, from cell growth and off-gas $\mathrm{CO}_{2}$ profile 
it is evident that cells were in the stationary phase and more prone to cell lysis due to the higher shear stress. The high agitation speed also helped to generate froth with the unconsumed fat causing loss of substrate bioavailability, resulting in lower cell biomass concentration and total lipid content for M. circinelloides in batch fermentation. Addition of antifoam, reduction of agitation speed, and lowering of the aeration were applied to control the cream formation. However, these measures were not effective, and the experiment was stopped after the creaming started. The occurrence of this kind of phenomenon was not found in glucose-grown $M$. circinelloides during batch fermentation experiments [32]. No cream formation was observed during the cultivation of M. alpina. Even though low biomass and lipid content were obtained at the end of batch fermentation. One of the possible reasons of creaming issue in $M$. circinelloides animal fat fermentation could be production of exopolysaccharides, but this would need to be confirmed in future studies.

The off-gas $\mathrm{CO}_{2}$ profile did not reflect real time growth in the fermenter, and growth and lipid formation were observed in both $M$. circinelloides and in M. alpina, despite a decrease in off-gas $\mathrm{CO}_{2}$ concentration. Similar findings are mentioned by Wynn and coworkers for glucose grown $M$. circinelloides [37]. The reason for this trend is that the drop in $\mathrm{CO}_{2}$ evolution indicates the exhaustion of nitrogen from cultures resulted from down regulation of cell metabolism. Thus, cells remain metabolically active by assimilating the substrate and producing the cells and lipids [37].

In the fed-batch fermentation, the exponential feeding was chosen to achieve high cell concentrations and, subsequently, the high total lipid content. The growth rate applied for both strains, during exponential feeding, was half of the maximum growth rate determined from their batch fermentations. The lower concentration of animal fat byproduct $(8 \mathrm{~g} / \mathrm{L})$ was used in batch phase to avoid cream formation during $M$. circinelloides cultivation. Despite this cream was generated during feed phase during $M$. circinelloides fermentation. As previously, this resulted in low biomass concentration and lipid content at the end of the $M$. circinelloides experiment. In the fed-batch growth of M. alpina, biomass concentration at the end of the batch phase was comparable to that obtained in batch fermentation. However, it was lower than expected when fed-batch fermentation was completed. Lipid content in M. alpina was almost stable during complete experiment, and it was not affected by the exponential feeding. During the feed phase, biomass concentration of $M$. circinelloides and M. alpina increased initially following the feed profile and dropped surprisingly after substantial feeding. A possibility of the nitrogen source depletion being responsible for this biomass decrease can be disregarded considering that the feed media contained nitrogen source and that it was fed continuously. The effect of nitrogen source on growth and lipid biosynthesis by oleaginous microorganisms has been reported by many studies [26,38,39], and it has been identified that the nitrogen depletion mainly triggers the lipid formation in Mortierella and Mucor strains [40-43]. One possible reason for the biomass decrease might be potential limitation of mineral salts and trace elements. This might be because the composition of salt solution in fed batch media (Section 2.2) was kept constant while other media components were adjusted to the concentration of the substrate (animal fat). The effect of different mineral salts and media components on growth and lipid accumulation in $M$. circinelloides and M. alpina has been studied and their necessity for growth of these strains has been underlined [21,44]. Further research is needed to identify the exact cause for low biomass concentration obtained in this study.

GLA was produced by both $M$. circinelloides and $M$. alpina whereas ARA production was attributed to only M. alpina when grown on animal fat. None of these strains produced docosahexaenoic acid (DHA) when animal fat was used as substrate. The ARA content obtained in batch cultivation of M. alpina on fat was very low, and the main reason for it was not investigated in this study. M. alpina grown on glucose showed higher content of ARA compared to the animal fat cultivations, and it was comparable to the previously reported results [32]. In all the fat-based experiments, ARA content of M. alpina followed the biomass profile i.e., showed an increase with the increase in biomass. Such a growth coupled synthesis of ARA was also found in previous studies for M. alpina, LPM-301, 
and NRRL-A-10995 [31,35]. The effect of increase in growth rate on ARA production was also observed in our study. The ARA production was increased (from 10 to $24 \%_{\mathrm{wt}}$ ) during exponential feeding in fed batch experiment. Similar results were also mentioned in literature supporting the growth-associated ARA synthesis [35].

\section{Conclusions}

The use of animal fat by-products as substrate for the production of value-added fatty acids using fungal strains $M$. circinelloides and M. alpina was reported for the first time in this study, indicating that these strains may be suitable for industrial valorization of low-quality fat by-products. Both strains exhibited growth on waste animal fat during shake flask, batch, and fed-batch cultivations in fermenters and produced cells of comparable lipid content. When grown on fat, both strains produced Gamma-linolenic acid whereas only M. alpina produced arachidonic acid during exponential growth phase. No docosahexanoic acid was found in either biomass produced.

Author Contributions: Conceptualization, S.S.G., C.B. and V.S.; methodology, S.S.G., S.S.R. and J.B.; validation, S.S.G., S.S.R. and J.B.; formal analysis, J.B. and B.Z.; investigation, S.S.G. and S.S.R.; resources, V.S. and C.B.; writing—original draft preparation, S.S.G.; writing—review and editing, S.S.G., J.B., B.Z., M.O., A.K., V.S. and C.B.; visualization, S.S.G.; supervision, V.S. and C.B.; project administration, A.K., V.S. and C.B.; funding acquisition, A.K., V.S. and C.B. All authors have read and agreed to the published version of the manuscript.

Funding: This research was funded by the Research Council of Norway, the BIONÆR Grant, project number 268305/E50; the MATFONDAVTALE Grant, project number 301834/E50, the HAVBRUK 2 Grant, project number 302543/E40 and SFI Grant, project number 309558.

Institutional Review Board Statement: Not applicable.

Informed Consent Statement: Not applicable.

Data Availability Statement: This study did not report any data.

Conflicts of Interest: The authors declare no conflict of interest.

\section{References}

1. OECD/Food and Agriculture Organization of United Nations. Meat, OECD-FAO Agriculture Outlook 2021-2030; Food and Agriculture Organization of United Nations: Rome, Italy; OECD: Paris, France, 2021.

2. Woodgate, S.L.; van der Veen, J.T. Fats and Oils-Animal Based. In Food Processing: Principles and Application, 2nd ed.; Clark, S., Jung, S., Lamsal, B., Eds.; John Wiley \& Sons: Hoboken, NJ, USA, 2014.

3. Marova, I.; Szotkowski, M.; Vanek, M.; Rapta, M.; Byrtusova, D.; Mikheichyk, N.; Haronikova, A.; Certik, M.; Shapaval, V. Utilization of animal fat waste as carbon source by carotenogenic yeasts-A screening study. EuroBiotech J. 2017, 1, 310-318. [CrossRef]

4. Rosson, E.; Sgarbossa, P.; Pedrielli, F.; Mozzon, M.; Bertani, R. Bioliquids from raw waste animal fats: An alternative renewable energy source. Biomass Convers. Biorefinery 2020, 11, 1475-1490. [CrossRef]

5. Toldrá-Reig, F; Mora, L.; Toldrá, F. Trends in Biodiesel Production from Animal Fat Waste. Appl. Sci. 2020, 10, 3644. [CrossRef]

6. Chakraborty, R.; Gupta, A.K.; Chowdhury, R. Conversion of slaughterhouse and poultry farm animal fats and wastes to biodiesel: Parametric sensitivity and fuel quality assessment. Renew. Sustain. Energy Rev. 2014, 29, 120-134. [CrossRef]

7. Sai Akhil, U.; Alagumalai, A. A Short Review on Valorization of Slaughterhouse Wastes for Biodiesel Production. ChemistrySelect 2019, 4, 13356-13362. [CrossRef]

8. Papanikolaou, S.; Aggelis, G. Lipids of oleaginous yeasts. Part I: Biochemistry of single cell oil production. Eur. J. Lipid Sci. Technol. 2011, 113, 1031-1051. [CrossRef]

9. Adhikari, B.B.; Chae, M.; Bressler, D.C. Utilization of Slaughterhouse Waste in Value-Added Applications: Recent Advances in the Development of Wood Adhesives. Polymers 2018, 10, 176. [CrossRef]

10. Papanikolaou, S.; Chevalot, I.; Komaitis, M.; Marc, I.; Aggelis, G. Single cell oil production by Yarrowia lipolytica growing on an industrial derivative of animal fat in batch cultures. Appl. Microbiol. Biotechnol. 2002, 58, 308-312. [CrossRef]

11. El-Bialy, H.; Bullet, B.; Gomaa, O.; Khaled, B.; Azab, K. Conversion of oil waste to valuable fatty acids using Oleaginous yeast. J. Microbiol. Biotechnol. 2011, 27, 2791-2798. [CrossRef]

12. Weiss, R.; Eischer, A.; Tadic, T.; Gritsch, S.M.; Ortner, M.; Prall, K.; Neunteufel, E.; Putz, R.F.; Guebitz, G.M.; Nyanhongo, G.S. Valorisation of slaughter house and deinking paper waste streams for the production of enzyme by Trichoderma reesei. J. Clean. Prod. 2020, 275, 122882. [CrossRef] 
13. Szotkowski, M.; Byrtusova, D.; Haronikova, A.; Vysoka, M.; Rapta, M.; Shapaval, V.; Marova, I. Study of Metabolic Adaptation of Red Yeasts to Waste Animal Fat Substrate. Microorganisms 2019, 7, 578. [CrossRef] [PubMed]

14. Slaný, O.; Klempová, T.; Shapaval, V.; Zimmermann, B.; Kohler, A.; Čertík, M. Biotransformation of Animal Fat-By Products into ARA-Enriched Fermented Bioproducts by Solid-State Fermentation of Mortierella alpina. J. Fungi 2020, 6, 236. [CrossRef]

15. Byrtusová, D.; Szotkowski, M.; Kurowska, K.; Shapaval, V.; Márová, I. Rhodotorula kratochvilovae CCY 20-2-26-The Source of Multifunctional Metabolites. Microorganisms 2021, 9, 1280. [CrossRef]

16. Slaný, O.; Klempová, T.; Shapaval, V.; Zimmermann, B.; Kohler, A.; Čertík, M. Animal Fat as a Substrate for Production of n-6 Fatty Acids by Fungal Solid-State Fermentation. Microorganisms 2021, 9, 170. [CrossRef]

17. Marova, I.; Rapta, M.; Vanek, M.; Haronikova, A.; Szotkowski, M.; Shapaval, V. Use of high-throughput techniques to study simultaneous production of lipid metabolites in carotenogenic yeasts grown on waste animal fat. J. Biotechnol. 2017, 256, S42. [CrossRef]

18. Tzimorotas, D.; Afseth, N.K.; Lindberg, D.; Kjørlaug, O.; Axelsson, L.; Shapaval, V. Pretreatment of different food rest materials for bioconversion into fungal lipid-rich biomass. Bioprocess Biosyst. Eng. 2018, 41, 1039-1049. [CrossRef] [PubMed]

19. Kosa, G.; Kohler, A.; Tafintseva, V.; Zimmermann, B.; Forfang, K.; Afseth, N.K.; Tzimorotas, D.; Vuoristo, K.S.; Horn, S.J.; Mounier, J.; et al. Microtiter plate cultivation of oleaginous fungi and monitoring of lipogenesis by high-throughput FTIR spectroscopy. Microb. Cell Factories 2017, 16, 101. [CrossRef]

20. Kosa, G.; Zimmermann, B.; Kohler, A.; Ekeberg, D.; Afseth, N.K.; Mounier, J.; Shapaval, V. High-throughput screening of Mucoromycota fungi for production of low- and high-value lipids. Biotechnol. Biofuels 2018, 11, 66. [CrossRef]

21. Dzurendova, S.; Zimmermann, B.; Tafintseva, V.; Kohler, A.; Ekeberg, D.; Shapaval, V. The influence of phosphorus source and the nature of nitrogen substrate on the biomass production and lipid accumulation in oleaginous Mucoromycota fungi. Appl. Microbiol. Biotechnol. 2020, 104, 8065-8076. [CrossRef]

22. Dzurendova, S.; Zimmermann, B.; Kohler, A.; Tafintseva, V.; Slany, O.; Certik, M.; Shapaval, V. Microcultivation and FTIR spectroscopy-based screening revealed a nutrient-induced co-production of high-value metabolites in oleaginous Mucoromycota fungi. PLoS ONE 2020, 15, e0234870. [CrossRef] [PubMed]

23. Dzurendova, S.; Zimmermann, B.; Tafintseva, V.; Kohler, A.; Horn, S.J.; Shapaval, V. Metal and Phosphate Ions Show Remarkable Influence on the Biomass Production and Lipid Accumulation in Oleaginous Mucor circinelloides. J. Fungi 2020, 6, 260. [CrossRef]

24. Dzurendova, S.; Zimmermann, B.; Kohler, A.; Reitzel, K.; Nielsen, U.G.; Dupuy-Galet, B.X.; Leivers, S.; Horn, S.J.; Shapaval, V. Calcium Affects Polyphosphate and Lipid Accumulation in Mucoromycota Fungi. J. Fungi 2021, 7, 300. [CrossRef]

25. Athenaki, M.; Gardeli, C.; Diamantopoulou, P.; Tchakouteu, S.S.; Sarris, D.; Philippoussis, A.; Papanikolaou, S. Lipids from yeasts and fungi: Physiology, production and analytical considerations. J. Appl. Microbiol. 2018, 124, 336-367. [CrossRef] [PubMed]

26. Caporusso, A.; Capece, A.; De Bari, I. Oleaginous Yeasts as Cell Factories for the Sustainable Production of Microbial Lipids by the Valorization of Agri-Food Wastes. Fermentation 2021, 7, 50. [CrossRef]

27. Ratledge, C. Fatty acid biosynthesis in microorganisms being used for Single Cell Oil production. Biochimie 2004, 86, 807-815. [CrossRef] [PubMed]

28. Mhlongo, S.I.; Ezeokoli, O.T.; Roopnarain, A.; Ndaba, B.; Sekoai, P.T.; Habimana, O.; Pohl, C.H. The Potential of Single-Cell Oils Derived From Filamentous Fungi as Alternative Feedstock Sources for Biodiesel Production. Front. Microbiol. $2021,12,57$. [CrossRef]

29. Patel, A.; Karageorgou, D.; Rova, E.; Katapodis, P.; Rova, U.; Christakopoulos, P.; Matsakas, L. An Overview of Potential Oleaginous Microorganisms and Their Role in Biodiesel and Omega-3 Fatty Acid-Based Industries. Microorganisms 2020, 8, 434. [CrossRef] [PubMed]

30. McIntyre, M.; Breum, J.; Arnau, J.; Nielsen, J. Growth physiology and dimorphism of Mucor circinelloides (syn. racemosus) during submerged batch cultivation. Appl. Microbiol. Biotechnol. 2002, 58, 495-502. [CrossRef] [PubMed]

31. Mironov, A.A.; Nemashkalov, V.A.; Stepanova, N.N.; Kamzolova, S.V.; Rymowicz, W.; Morgunov, I.G. The Effect of pH and Temperature on Arachidonic Acid Production by Glycerol-Grown Mortierella alpina NRRL-A-10995. Fermentation $2018,4,17$. [CrossRef]

32. Kosa, G.; Vuoristo, K.S.; Horn, S.J.; Zimmermann, B.; Afseth, N.K.; Kohler, A.; Shapaval, V. Assessment of the scalability of a microtiter plate system for screening of oleaginous microorganisms. Appl. Microbiol. Biotechnol. 2018, 102, 4915-4925. [CrossRef]

33. Lewis, T.; Nichols, P.D.; McMeekin, T.A. Evaluation of extraction methods for recovery of fatty acids from lipid-producing microheterotrophs. J. Microbiol. Methods 2000, 43, 107-116. [CrossRef]

34. Langseter, A.M.; Dzurendova, S.; Shapaval, V.; Kohler, A.; Ekeberg, D.; Zimmermann, B. Evaluation and optimisation of direct transesterification methods for the assessment of lipid accumulation in oleaginous filamentous fungi. Microb. Cell Factories 2021, 20, 59. [CrossRef]

35. Eroshin, V.K.; Satroutdinov, A.D.; Dedyukhina, E.G.; Chistyakova, T.I. Arachidonic acid production by Mortierella alpina with growth-coupled lipid synthesis. Process. Biochem. 2000, 35, 1171-1175. [CrossRef]

36. Heeres, A.S.; Picone, C.S.F.; van der Wielen, L.A.M.; Cunha, R.L.; Cuellar, M.C. Microbial advanced biofuels production: Overcoming emulsification challenges for large-scale operation. Trends Biotechnol. 2014, 32, 221-229. [CrossRef]

37. Wynn, J.P.; Hamid, A.A.; Li, Y.; Ratledge, C. Biochemical events leading to the diversion of carbon into storage lipids in the oleaginous fungi Mucor circinelloides and Mortierella alpina. Microbiology 2001, 147, 2857-2864. [CrossRef] [PubMed] 
38. Papanikolaou, S.; Galiotou-Panayotou, M.; Fakas, S.; Komaitis, M.; Aggelis, G. Lipid production by oleaginous Mucorales cultivated on renewable carbon sources. Eur. J. Lipid Sci. Technol. 2007, 109, 1060-1070. [CrossRef]

39. Chen, H.; Hao, G.; Wang, L.; Wang, H.; Gu, Z.; Liu, L.; Zhang, H.; Chen, W.; Chen, Y.Q. Identification of a critical determinant that enables efficient fatty acid synthesis in oleaginous fungi. Sci. Rep. 2015, 5, 11247. [CrossRef]

40. Kavadia, A.; Komaitis, M.; Chevalot, I.; Blanchard, F.; Marc, I.; Aggelis, G. Lipid and $\gamma$-linolenic acid accumulation in strains of zygomycetes growing on glucose. J. Am. Oil Chem. Soc. 2001, 78, 341-346. [CrossRef]

41. Jang, H.-D.; Lin, Y.-Y.; Yang, S.-S. Effect of culture media and conditions on polyunsaturated fatty acids production by Mortierella alpina. Bioresour. Technol. 2005, 96, 1633-1644. [CrossRef] [PubMed]

42. Xia, C.; Zhang, J.; Zhang, W.; Hu, B. A new cultivation method for microbial oil production: Cell pelletization and lipid accumulation by Mucor circinelloides. Biotechnol. Biofuels 2011, 4, 15. [CrossRef]

43. Tang, X.; Zan, X.; Zhao, L.; Chen, H.; Chen, Y.Q.; Chen, W.; Song, Y.; Ratledge, C. Proteomics analysis of high lipid-producing strain Mucor circinelloides WJ11: An explanation for the mechanism of lipid accumulation at the proteomic level. Microb. Cell Factories 2016, 15, 35. [CrossRef] [PubMed]

44. Nagao Totani, A.Y.; Yawata, M.; Ueda, T. The Role of Morphology during Growth of Mortierella alpina in Arachidonic Acid Production. J. Oleo Sci. 2002, 51, 531-538. [CrossRef] 